\title{
Vis klør mot juristeriet!
}

\author{
I den senere tid er helsevesenet blitt stadig mer lovregulert. Stadig \\ oftere henvises det til paragrafer og lovpålagte plikter istedenfor til \\ pasientens beste. Herved oppfordres leger og andre helsearbeidere \\ til å la eget klinisk og medmenneskelig skjønn gå foran meningsløst \\ regelrytteri.
}

Jeg har tidligere skrevet som gjesteskribent i Tidsskriftet om juristenes og reglenes problematiske inntog i helsevesenet (1). Der oppfordret jeg leger til å stå imot presset om ensidig å følge lovens bokstav hvis dere ser dette fører galt av sted og resultatet ikke er forenlig med god faglighet. Denne kampen er ikke vunnet ennå. Fortsatt møter pasienter helsearbeidere som forteller at de dessverre

\section{Når loven blir målet}

Går vi til helsesektoren, er inntrykket ofte at helsearbeidere har misforstått og ser det som sin hovedoppgave å oppfylle loven. Da er man på trygg grunn. Ingen kritikk og intet erstatningskrav å frykte. For øvrig er dette ikke bare helsevesenets problem. En vernepleier fortalte oppgitt om en utviklingshemmet liten gutt som omsorgsarbeiderne

\section{«Det er bekymringsfullt hvis leger og kontroll- myndigheter gjemmer seg bak reglene istedenfor å ta ansvar for pasientenes beste.»}

ikke kan gjøre det som åpenbart er fornuftig - fordi lovgiveren har bestemt at de skal gjøre noe annet.

\section{Innen juridiske rammer}

Vi lever i en rettsstat der legalitetsprinsippet er grunnleggende. Dette prinsippet handler om at myndighetene ikke kan gripe inn $\mathrm{i}$ borgernes rettssfære uten at det som gjøres er forankret i lov. De folkevalgte skal på denne måten beskytte den enkelte mot vilkårlighet fra personer og organer som forvalter offentlig myndighet. Legalitetsprinsippet skal sikre forutsigbarhet, likhet for loven og hindre vilkårlig maktutøvelse fra politi, skatte- og bygningsmyndigheter og andre. I helsevesenet er legalitetsprinsippet viktig i de situasjoner der leger og andre har myndighet til å treffe beslutninger som griper inn $\mathrm{i}$ vår private sfære, som når de vil tvangsinnlegge oss, videresende hele eller deler av sykejournalen eller frata oss førerkortet.

Lovgivningen setter rammer for slike inngrep. Det er viktig både for legen som forvalter denne type makt og for den enkelte pasient. Samtidig er det å oppfylle lovens krav ikke noe mål i seg selv. Lovreglene er verktøyet som skal sikre et godt resultat. Loven kan sammenliknes med hammeren vi bruker for å henge opp et bilde på veggen. Målet er å få bildet på plass, hammeren hjelpemidlet vi trenger for å få det til. ikke lenger kunne ta med på svømming til tross for at han elsket å bade. Han måtte alltid hales opp av vannet. I juridisk forstand var dette tvang og derfor forbudt. For denne lille gutten ble rettsregler som skal beskytte ham isteden brukt til å frata ham en åpenbar glede. Det kan umulig ha vært Stortingets mening med å lovregulere bruk av tvang og makt mot utviklingshemmede. Eksemplet viser hvor galt det kan gå hvis man ensidig fokuserer på å opptre juridisk korrekt på bekostning av sunn fornuft (2).

I helsesektoren er pasientrettigheter viktige for å sikre nødvendig og god medisinsk hjelp. Men som pasienter ønsker vi ikke at rettighetene skal brukes til å frata oss leger som anvender sitt eget faglig medisinske skjønn.

En situasjon mange pasienter opprøres over, er at de av formelle grunner nektes helsehjelp på det stedet deres nærmeste pårørende bor. Et eksempel til illustrasjon: Per og Kari er samboere, men har beholdt sine egne boliger forskjellige steder i landet. Kari som har registrert bopel i Trondheim, utsettes for en alvorlig ulykke der. Av grunner alle forstår, ber hun om å bli overflyttet fra Trondheim til et lokalsykehus i nærheten av Per som bor i Larvik. Hun får det til slutt til, men først etter en hard kamp med «systemet» som insisterer på at det er hennes boligadresse som avgjør, ikke hvor hun kan få tilsyn og omsorg.

Det sterke fokus på jus og formaliteter preger også tilsynsmyndighetenes praksis. Inntrykket er at man er mer opptatt av å telle små og store lovavvik og opptre formelt korrekt enn å ta ansvar for pasientenes situasjon. En pårørende reagerte på nettopp dette. Hun hadde sin mor på sykehjem og klaget til Fylkeslegen over behandlingen. Fylkeslegen tok affære og morens situasjon ble bedre. Datterens nye bekymring gjaldt alle de andre beboerne. Fylkeslegen hadde begrenset seg til å gripe inn i morens situasjon, men ikke hjulpet alle dem som ikke hadde fremmet noen formell klage. Hvorfor hadde Fylkeslegen utvist så liten ansvarsfølelse overfor disse, undret datteren.

En fersk klagesak illustrerer samme problem: En pasient i psykiatrien klaget til helsetilsynet i fylket over at man opprettholdt et vedtak om tvangsmedisinering når hun nå tok medisin frivillig. I klagen hevdet pasienten at sykehuset handlet $i$ strid med hennes rett til respekt for privatlivet, jf. art. 8 i Den europeiske menneskerettighetskonvensjon (EMK) som har prioritet foran norsk lov, jf. § 3 i menneskerettighetsloven. Klagen ble avvist blant annet med denne begrunnelse: «For prøving av menneskerettigheter Norge har sluttet seg til, er ikke fylkesmannen eller kontrollkommisjonen tildelt noen spesifikk rolle.»Dette er direkte galt i juridisk forstand. Svaret gir samtidig inntrykk av at klageorganet er mer opptatt av det de mener er korrekt saksbehandling enn av å beskytte en pasient mot å bli krenket.

Det er bekymringsfullt hvis leger og kontrollmyndigheter gjemmer seg bak reglene istedenfor å ta ansvar for pasientenes beste. Derfor oppfordrer jeg dere leger til å bruke den makten dere har til å vise klør mot juristeriet og slåss for retten til å praktisere på grunnlag av egne faglig medisinske vurderinger, medmenneskelighet og sunn fornuft.

\section{Gro Hillestad Thune}

gro.thune@getmail.no

Advokat og menneskerettighetsrådgiver

Anton Schjøths g. 13

0454 Oslo

\section{Oppgitte interessekonflikter: Ingen}

\footnotetext{
Litteratur

1. Thune GH. Det gode medisinske skjønn er viktigst Tidsskr Nor Lægeforen 2007; 127: 140

2. Thune GH. Overgrep. Søkelys på psykiatrien. Oslo: Abstrakt forlag, 2008.
}

Manuskriptet ble mottatt 9.10. 2008 og godkjent 3.3. 2009. Medisinsk redaktør Anne Kveim Lie. 